OPEN ACCESS

Edited by:

Gema Perez-Chacon,

Spanish National Cancer Research

Center (CNIO), Spain

Reviewed by:

Ignacio Moreno De Alborán,

Consejo Superior de Investigaciones

Científicas (CSIC), Spain

Anne Corcoran

Babraham Institute (BBSRC),

United Kingdom

${ }^{*}$ Correspondence:

Yves Denizot

yves.denizot@unilim.fr

Specialty section:

This article was submitted to

B Cell Biology,

a section of the journal

Frontiers in Immunology

Received: 29 April 2020

Accepted: 15 June 2020

Published: 23 July 2020

Citation:

Ferrad M, Ghazzaui N, Issaoui H, Cook-Moreau J and Denizot Y (2020) Mouse Models of c-myc Deregulation

Driven by IgH Locus Enhancers as Models of B-Cell Lymphomagenesis.

Front. Immunol. 11:1564

doi: 10.3389/fimmu.2020.01564

\section{Mouse Models of c-myc Deregulation Driven by IgH Locus Enhancers as Models of B-Cell Lymphomagenesis}

\author{
Melissa Ferrad, Nour Ghazzaui, Hussein Issaoui, Jeanne Cook-Moreau and Yves Denizot*
}

Inserm U1262, UMR CNRS 7276, Equipe Labellisée LIGUE 2018, Université de Limoges, Limoges, France

Chromosomal translocations linking various oncogenes to transcriptional enhancers of the immunoglobulin heavy chain $(\mathrm{lgH})$ locus are often implicated as the cause of B-cell malignancies. Two major lgH transcriptional enhancers have been reported so far. The $E_{\mu}$ enhancer located upstream of the $C_{\mu}$ gene controls early events in B-cell maturation such as VDJ recombination. The 3' regulatory region (3'RR) located downstream from the $\mathrm{C}_{\alpha}$ gene controls late events in $\mathrm{B}$-cell maturation such as $\mathrm{IgH}$ transcription, somatic hypermutation, and class switch recombination. Convincing demonstrations of the essential contributions of both $E_{\mu}$ and $3^{\prime} R R$ in B-cell lymphomagenesis have been provided by transgenic and knock-in animal models which bring the oncogene c-myc under $E_{\mu} / 3$ 'RR transcriptional control. This short review summarizes the different mouse models so far available and their interests/limitations for progress in our understanding of human c-myc-induced B-cell lymphomagenesis.

Keywords: MYC, B-cell lymphoma, transgenic mouse models, IgH locus, IgH transcriptional enhancers

\section{INTRODUCTION}

RAG-induced recombination, AID-induced DNA breaks and mutations throughout B-cell development make the IgH locus a hotspot for translocations (1) (Figures 1A,B). Bcl-2 translocation, the typical hallmark of follicular lymphomas (FL), occurs during RAG-induced VDJ recombination. Cyclin D1 translocation, associated with mantle cell lymphomas (MCL), occurs either during AID-induced somatic hypermutation (SHM) or AID-induced class switch recombination (CSR). C-myc translocation, the typical hallmark of Burkitt lymphoma (BL), takes place during AID-induced SHM and CSR. Finally, several translocations (such as $c$-myc, c-maf, cyclin D1/D3) found in myelomas are also related to AID-induced CSR. During CSR, AID-induced DNA double strand breaks (DSB) appear in the switch $(S)$ donor region (usually $S_{\mu}$ ) and in the $S$ acceptor region (for example $S_{\gamma 1}$ and $S_{\alpha}$ for CSR toward IgG1 and IgA, respectively). $S$ regions are of various lengths (for example 3.5 and $10 \mathrm{~kb}$ long for $S_{\mu}$ and $S_{\gamma 1}$, respectively) and are unusually G-rich. AID deaminates $C$ into $U$ at preferential AID hotspot motifs located throughout $S$ regions. The AID-introduced U in $S$ region DNA is removed by UNG to generate an abasic site that is recognized by the endonuclease APE1 generating a nick. A closely spaced, similarly created nick on the opposite strand induces a staggered DSB. Translocation of the DNA fragment encompassing $c-m y c$ is due to an off target AID effect on the chromosome bearing $c-m y c$. Since AID transforms C to $\mathrm{U}$ all along $S$ donor/acceptor regions, there is no common breakpoint identified in $S$ regions for mature B-cell lymphomas. It is the same AID effect for SHM where AID targets the VDJ rearranged segments (and up to several $\mathrm{kB}$ in $3^{\prime}$ ) and can induce DNA DSB for $c$-myc translocation. Similarly to CSR, there is no common breakpoint established in VDJ regions for mature B-cell lymphomas. 
During VDJ recombination RAG binds to recombination signal sequences adjacent to $\mathrm{V}, \mathrm{D}$, and $\mathrm{J}$ coding segments and induces DNA DSB. C-myc translocation could take place during this process. Similarly to CSR/SHM, there is no common breakpoint singled out in VDJ regions for B-cell lymphomas. The common point for all these c-myc translocations is the occurrence of DSB in the IgH locus during its remodeling required for Bcell repertoire formation and B-cell maturation. All remodeling events of the IgH locus (VDJ recombination, SHM, and CSR) require transcription to occur (2). Transcriptional control and remodeling of the $\mathrm{IgH}$ locus are under the control of several cis-regulatory elements located throughout the IgH locus. In the murine $\mathrm{IgH}$ locus seven regions of interest can be defined including cis-regulatory elements, matrix attachment regions (MARs), and hypersensitivity (hs) sites with potential transcriptional enhancer or insulator activity: 4 hs sites located 5' of the first $\mathrm{V}$ segments, 6 hs sites in the $\mathrm{V}-\mathrm{D}$ intergenic region, the DQ52 promoter-enhancer, the $\mathrm{E}_{\mu}$ enhancer (between $\mathrm{J}_{\mathrm{H}}$ and $C_{\mu}$ ) and its flanking MARs, the $\gamma 1$ enhancer element, the 3' regulatory region ( $3^{\prime} R R$ ) downstream from $\mathrm{C}_{\alpha}$ with its four enhancers (hs3a, hs1,2, hs3b, and 4) and the 3'CBE insulator region (hs5, $6,7,8)$ as the 3 ' boundary of the locus (Figure 1A). Two potent transcriptional enhancers act during B-cell maturation: $\mathrm{E}_{\mu}$ (during early B-cell maturation stages) and 3'RR (during late B-cell maturation stages) (Figure 1A). These elements obviously intervene in oncogene-induced B-cell lymphomagenesis as reported by several transgenic mouse models (using both transgene and knock-in (KI) strategies) developed in order to mimic human mature B-cell lymphomagenesis. Since c-myc is a key regulator of cell growth through its action on cell cycle progression, metabolism, differentiation, death receptor signaling, and DNA damage recovery, the vast majority of available models use $c-m y c$ as a deregulated oncogene (3). This short review describes how $\mathrm{E}_{\mu}$ and 3'RR enhancers might play a critical role in $c$-myc deregulation during $\mathrm{c}$-myc-induced mature B-cell lymphomas, why these models are not silver bullets to totally mimic human B-cell lymphomagenesis and why it is possible that targeting the $3^{\prime} \mathrm{RR}$ would be an interesting strategy in human B-cell lymphomagenesis.

\section{THE $E_{\mu}$ cis-TRANSCRIPTIONAL IGH ENHANCER AND $c-m y c$ DEREGULATION}

Forty years ago, $\mathrm{E}_{\mu}$ was the first discovered $\operatorname{IgH}$ cistranscriptional enhancer (4-6). It is located upstream of the $\mathrm{C}_{\mu}$ gene (Figure 1A). $\mathrm{E}_{\mu}$-deficient mice revealed its role in controlling IgH locus access at immature B-cell stages and thus its key role for efficient VDJ recombination $(7,8)$. In contrast, $\mathrm{E}_{\mu}$ is dispensable for late B-cell maturation events such as $\operatorname{IgH}$ locus transcription for Ig synthesis and CSR (9, 10). In 1985, transgenic mice bearing $c-m y c$ coupled to the $\mathrm{E}_{\mu}$ enhancer were reported to consistently develop immature (pre-B) and sometimes mature B-cell lymphomas (11). Our entire knowledge of $\mathrm{E}_{\mu}$ involvement in $c$-myc oncogenic deregulation for B-cell lymphoma development was built from this model. Since 1985, 183 papers with " $\mathrm{E}_{\mu}-M y c$ mice" in their abstract have been referenced. Of note, 153 have been published in the last 15 years showing the great interest of the scientific community for this transgenic mouse model of B-cell lymphoma. It is thus impossible in this short review to reference them all. Therefore, the authors apologize in advance for the numerous interesting manuscripts which have not been cited in the present review. Lymphomas from $\mathrm{E} \mu$-Myc mice range from the pre-B to the mature B-cell stages (Figure 1C). They are usually all positive for the CD45R (B220), CD19 and CD93 (AA4.1) B-cell specific markers and negative for the CD3 T-cell marker. Tumors of pre-B-cell type are characterized by the lack of membrane IgM and no Ig light chain (IgL) rearrangements. Tumors of immature B-cell types are more mature and express membrane IgM after efficient IgL rearrangements. Tumors of mature B-cell types are even more mature and express both membrane IgM and IgD. The majority of lymphomas in $\mathrm{E} \mu-\mathrm{Myc}$ mice are at the pre-B and immature Bcell stages. In their original study, Adams et al. (11) stated that "these myc mice should aid study of lymphoma development, B-cell ontogeny and Ig regulation." Clearly 35 years later this is the case. Creation of these mice resulted in the dissection of many mechanisms implicated in B-cell lymphomagenesis (Figure 1D). They have highlighted the importance of several signaling pathways (such as Ras/Mapk, mTOR, and Akt) (1214), several cell cycle check-points (such as Mdm2/p53/p73) $(15,16)$ and processes that affect $c-m y c$ stability and action $(17,18)$. Using these mice clearly demonstrated the importance of numerous (new and well-known) tumor suppressor genes (such as FoxO3, CDK4, Mtap, and Smchd1) (19-22). This model reinforced our knowledge concerning the signaling/regulation of the B-cell apoptotic program (members of the Bcl-2 family of apoptosis regulator) and deficiencies in apoptotic pathways leading to B-cell lymphomagenesis (23-28). To our knowledge the influence of genetic background in the development of Bcell lymphomas in E $\mu-M y c$ mice has not been documented. The $\mathrm{E}_{\mu}-M y c$ model has also opened a new area of research concerning the role of tumor microenvironment via release of angiocrine/chemokine factors (29-31) and the importance of cells from the vascular niche for NK cell surveillance, senescence, and homing of B-cell lymphomas (32-34). Perhaps most importantly, this model is at the origin of a wide number of publications investigating new therapeutic treatments or combinations of drugs in order to affect (among various targets) DNA synthesis (cytarabine, doxyrubicin, cyclophosphamide), mTOR signaling (rapamycin analogs), microtubule formation (vincristine), c-myc (decursin), apoptosis (venetoclax and BET inhibitors), protein synthesis (silvestrol), or B-cell receptor (BCR)-induced, or chemokine-mediated signaling (ibrutinib) (35-42). The rapid occurrence of lymphoma in $\mathrm{E}_{\mu}-M y c$ mice and its high penetrance make this mouse model an accurate, reliable, easy, and fast experimental model not only to test new therapeutic approaches but also combinatory associations. This model is also unique by providing the possibility to monitor the assay of new NK therapeutic vaccination strategies $(43,44)$, to stimulate immune defenses for tumor rejection (45) and to test protocols for monoclonal antibody therapies (46). $\mathrm{E}_{\mu}-M y c$ mice have thus proven their great potential as a model to study human B-cell lymphomagenesis during the 


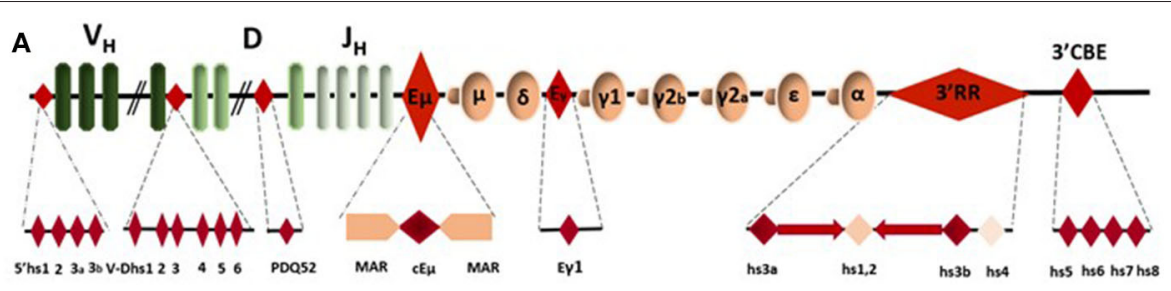

B

VDJ rearrangements

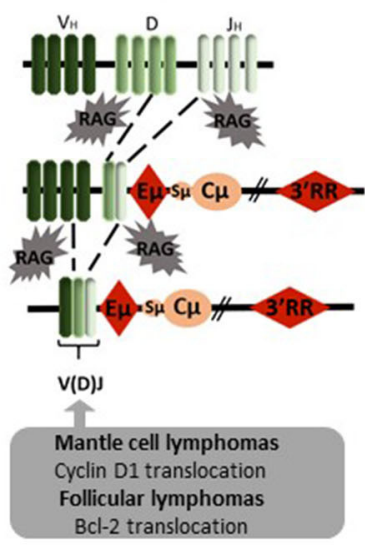

Class switch recombination

(CSR)

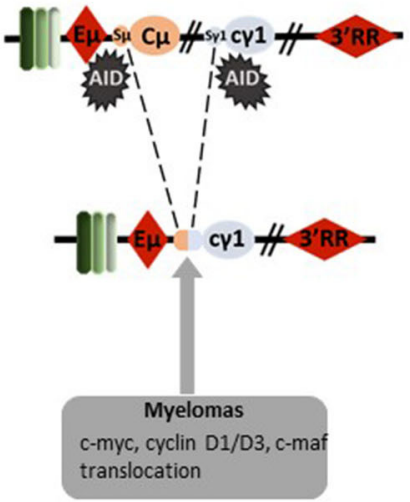

Somatic hymermutation

(SHM)

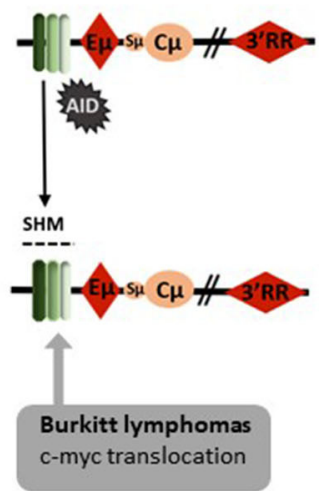

C

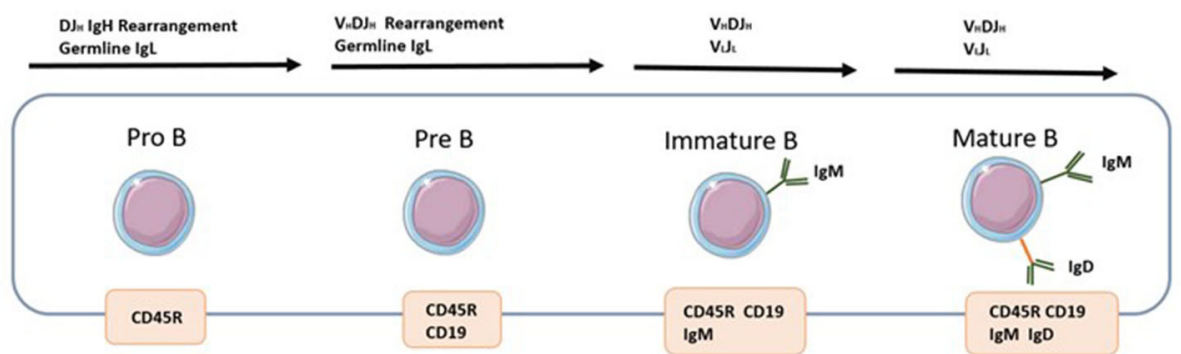

D

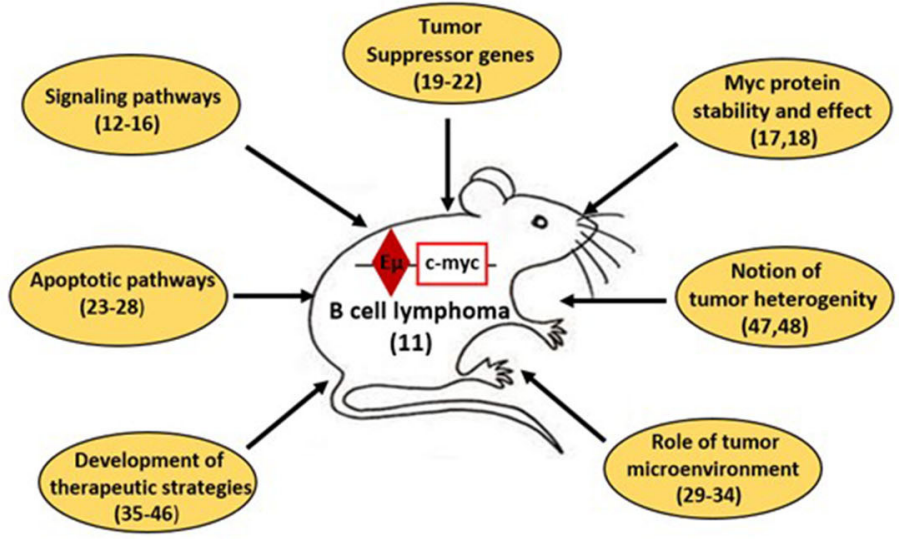

FIGURE $1 \mid E_{\mu}-M y c$ mice as a model of B-cell lymphomagenesis. (A) Schematic diagrams of the mouse lgH locus. Locations of the various IgH cis-regulatory elements with enhancer or insulator activity are reported: four hs sites located 5' of the first V segments, six hs sites in the V-D intergenic region, the DQ52 
FIGURE 1 | promoter-enhancer, the $E_{\mu}$ enhancer (the core region ( $C E \mu$ ) and its flanking MARs), the $\gamma 1$ enhancer, the 3' regulatory region (3'RR) [four enhancers (namely hs3a, hs1,2, hs3b, and 4) with flanking inverted repeats] and the 3'CBE insulator region (hs5, 6, 7, and 8) as the 3' boundary of the locus. (B) Schematic representation of oncogene translocation affecting the lgH locus during VDJ recombination, CSR and SHM. Arrows indicate the site of oncogene translocation found during follicular lymphomas, mantle cell lymphomas, myelomas, and Burkitt lymphomas. (C) Schematic representation of B-cell development from pro-B to mature B-cells. Lymphomas from $E_{\mu}-M y c$ mice are from the pre-B to the mature B-cell stages. The immature B-cell stage is characterized by the expression of membrane $\operatorname{lgM}$ whereas membrane $\operatorname{lgD}$ occurs at the mature B-cell stage. (D) Schematic representation of the various field of research developed with $E_{\mu}-M y c$ mice. Bibliographic references are reported (number in parenthesis).

past decade. Moreover, arising lymphomas are heterogeneous $(47,48)$ mirroring genomic differences observed between human $\mathrm{BL}$, germinal center B-cell lymphomas (GCBCL), activated Bcell lymphomas (ABCL), and diffuse large B-cell lymphomas (DLBCL). The different genomic signatures (toward specific proliferative and/or apoptotic pathways) of B-cell lymphomas in $\mathrm{E}_{\mu}-M y c$ mice might be used as biomarkers of response against specific therapeutic strategies. Thus, and especially with the development of transcriptomic tools, $\mathrm{E}_{\mu}-M y c$ mice can serve as relevant model for human B-cell lymphoma subtype experimental or associated treatments. The only but nevertheless major drawback of $\mathrm{E}_{\mu}-M y c$ mice relates to the window of activity for $\mathrm{E}_{\mu}$ which has been clearly demonstrated to occur at the immature pro-B/pre-B B-cell stages $(49,50)$. $\mathrm{E}_{\mu}$ is not implicated in $\mathrm{IgH}$ hypertranscription occurring at the mature/plasma cell stages. $\mathrm{E}_{\mu}$ is also not implicated in DNA breaks occurring during SHM/CSR and thus clearly not implicated in oncogenic translocation induced by off target AID action occurring during CSR or SHM in the majority of human mature B-cell lymphoma subtypes. As confirmation of this fact, the great majority of lymphomas from $\mathrm{E}_{\mu}-\mathrm{Myc}$ mice have a pre-B/immature $\mathrm{B}$ cell stage.

\section{THE 3'RR cis-TRANSCRIPTIONAL IgH ENHANCER AND $c-m y c$ DEREGULATION}

The second transcriptional enhancer located in the $\operatorname{IgH}$ locus is the $3^{\prime} \mathrm{RR}$ (Figure 1). The $3^{\prime} \mathrm{RR}$ is a complex element with four transcriptional enhancers (namely hs $3 \mathrm{a}, \mathrm{hs} 1,2$, hs $3 \mathrm{~b}$, and hs4) encompassed in a unique and functional 3D palindromic architecture (51). The 3'RR controls $\mu$ transcription (7), CSR $(52,53)$, and SHM $(54)$ in mature B-cells. The transcriptional activity of the 3'RR occurs from pre-B to mature B-cell stages (55) and thus has a much larger window of activity than the $\mathrm{E}_{\mu}$ enhancer. In 1994, Madisen and Groudine reported (in stable transfection assays in plasmacytomas and BL cells) that the 3 'RR was efficient and sufficient to deregulate c-myc transcription (56). Convincing demonstration of $3^{\prime} \mathrm{RR}$ involvement in lymphomagenesis has been produced by a transgenic 3'RR-deficient model of B-cell lymphomas with IgH$c-m y c$ translocations (57). The integrity of the $3^{\prime} \mathrm{RR}$ (deletion of hs3b to hs4) has been shown to be dispensable for development of pro-B-cell lymphomas with $\mathrm{V}(\mathrm{D}) \mathrm{J}$ recombination-initiated translocations suggesting the key role of $\mathrm{E}_{\mu}$. In contrast, $3^{\prime} \mathrm{RR}$ integrity (for its optimal transcriptional activity) is required for B-cell lymphomas with CSR-associated translocations (57). In another study modeling murine plasmacytomas with $\mathrm{T}(12,15)$ translocations, the same hs3b-hs4 deletion of the $3^{\prime} \mathrm{RR}$ in $\mathrm{Bcl}-$ $\mathrm{xL}$ transgenic mice was without effect for $M y c$ deregulation and mouse plasmacytoma generation (58). However, total 3'RR deletion in these plasmacytomas lowered Myc expression and cell growth confirming $3^{\prime} \mathrm{RR}$ involvement for myc deregulation by $\mathrm{T}(12,15)$. Nevertheless, these models are not sufficient to monitor in detail and to modulate signaling pathways for Bcell lymphoma development. The same comments can be made for the transgenic mouse model of Wang and Boxer (59) which develops mature B-cell lymphomas $\left(\mathrm{CD} 19^{+} \mathrm{B}_{220^{+}} \mathrm{IgM}^{+} \operatorname{IgD}{ }^{\text {low }}\right)$ after the KI of a 3'RR cassette upstream of the endogenous $c-m y c$ gene (this model is the reverse of natural $c$-myc translocation into the human IgH locus) (Figure 2). More than 15 years after the development of transgenic $\mathrm{E}_{\mu}-M y c$ mice, transgenic $M y c-3^{\prime} \mathrm{RR}$ mice were generated and were shown to develop BL-like proliferations and diffuse anaplastic B-cell lymphomas (60). All these lymphomas exhibited a mature B-cell phenotype $\left(\mathrm{CD} 19^{+} \mathrm{B}_{220^{+}} \mathrm{IgM}^{+} \operatorname{IgD}^{+}\right)$but differed by their Ki67 status (low and high for diffuse anaplastic B-cell lymphomas and BL lymphomas, respectively). This model was used to study the role of second hits such as p53 deficiency, Cdk4 mutation, and change of class-specific B cell receptor (BCR) tonic signals. Results clearly demonstrated that a second hit affects the phenotype of B-cell lymphomas, their aggressiveness and transcriptomic signatures differently (61-64). This model was, however, progressively abandoned due to its medium B-cell lymphoma penetrance (compared to $\mathrm{E}_{\mu}-M y c$ mice), long delay for B-cell lymphoma development (compared to $\mathrm{E}_{\mu}-M y c$ mice), key differences with human B-cell lymphomas (such as mutations lacking for the p53-ARF-Mdm2 apoptotic pathways in numerous cases) and the description that the occurrence of B-cell lymphomas was much too sensitive to genetic background [C57Bl/6 mice developed BLlike lymphomas while none occurred in a Balb/c background (65)]. All these points argued against the use of $M y c-3^{\prime} \mathrm{RR}$ mice as an accurate experimental model to test new pharmacologic or vaccination strategies.

\section{THE COMBINATION OF $E_{\mu}$ AND 3'RR cis-TRANSCRIPTIONAL ENHANCERS AND c-myc DEREGULATION}

As reported above, a transgenic model with $\mathrm{IgH}-c-m y c$ translocations in response to pristine demonstrated the involvement of $\mathrm{IgH}$ cis-transcriptional enhancers in B-cell lymphomagenesis (57). In another manner, this study confirmed results obtained with three transgenic mouse models with a $c-m y c \mathrm{KI}$ in various locations in the IgH locus (i.e., under the 


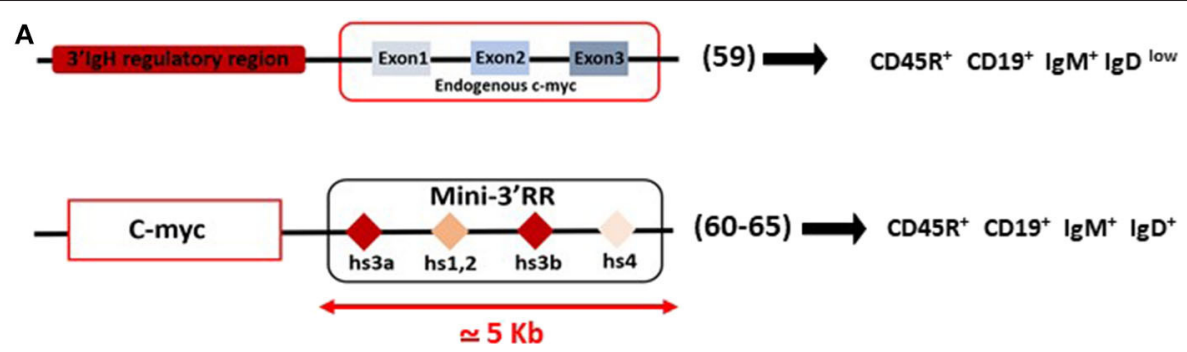

\section{Int

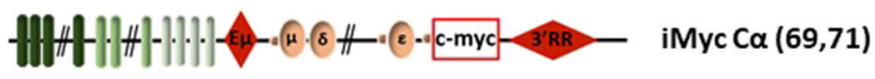

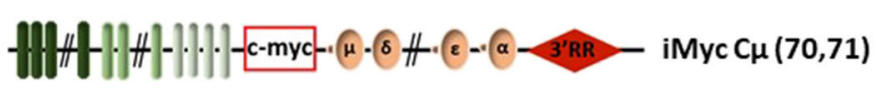 \\ $\mathrm{CD}^{2} \mathrm{R}^{+} \mathrm{CD}^{+9^{+}}$ \\ $\operatorname{lgM}^{+} \lg { }^{+/}$}

B
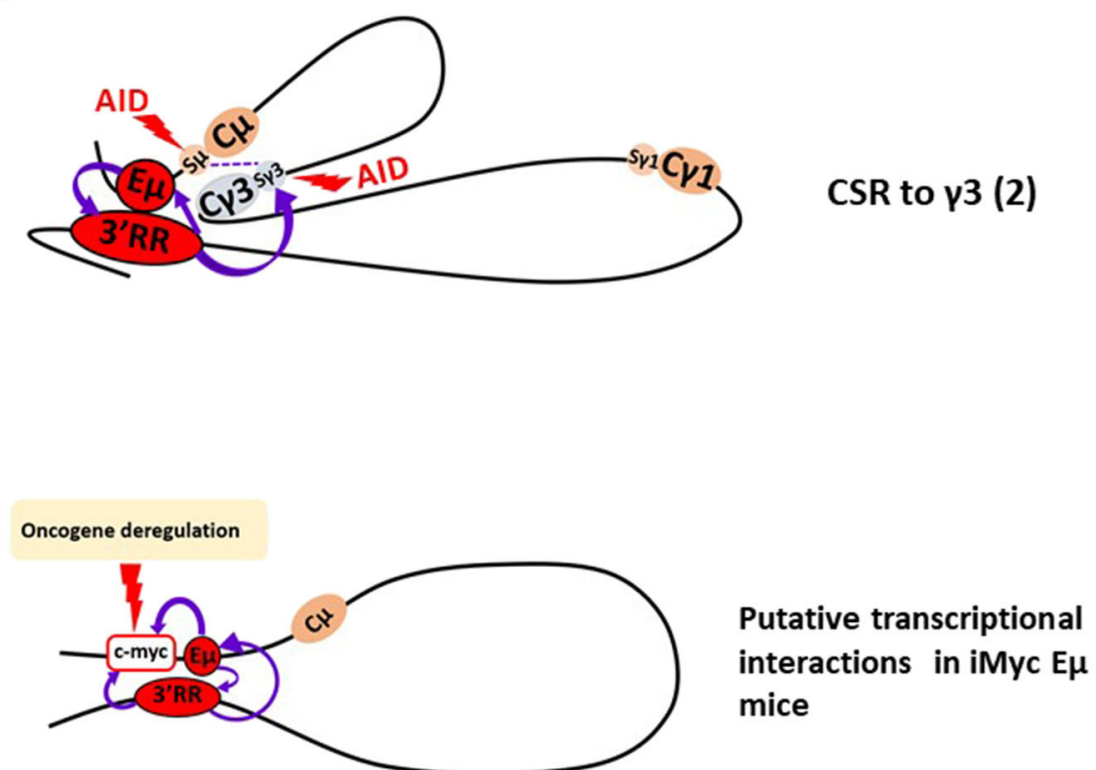

FIGURE 2 | The 3'RR and B-cell lymphomagenesis. (A) Schematic representation of several transgenic mouse models reporting c-myc 3'RR-driven deregulation leading to B-cell lymphomagenesis. B-cell lymphoma phenotypes are reported. Bibliographic references are reported (number in parenthesis). The "Mini-3'RR" contains the four transcriptional enhancers hs3a, hs 1,2, hs3b, and hs4 but not the 3'RR palindromic sequences flanking hs1,2 and the DNA sequence between hs3a and hs4. (B) Long-range loop interactions between chromatin segments of the lgH locus comprise the mechanism of normal gene transcription regulation by the $\mathrm{E}_{\mu}$ and 3'RR transcriptional enhancers. The example of the $\operatorname{lgG}_{3}$ CSR process is schematized. Putative long-range interactions leading to c-myc oncogene deregulation in $\mathrm{Myc}_{\mu}$ mice are schematized.

dependence of both $\mathrm{E}_{\mu}$ and 3'RR elements) (Figure 2). These models provided the most convincing data for the essential roles of both $\mathrm{E}_{\mu}$ and $3^{\prime} \mathrm{RR}$ in c-myc B-cell lymphomagenesis.
The KI of $c$-myc in the mouse IgH locus just $5^{\prime}$ to $\mathrm{E}_{\mu}$ (namely $\mathrm{i} M y c \mathrm{E}_{\mu}$ mice), thus modeling human endemic $\mathrm{BL}$, induced, as expected, B-cell lymphoma development with alterations 
in the p19 ${ }^{A r f}-M d m 2-p 53$ tumor suppressor axis (66) and NF?B/STAT3/PI3K signaling (67). In this model, $c-m y c$ is under the control of both $\mathrm{E}_{\mu}$ and $3^{\prime} \mathrm{RR}$ at immature and mature B-cell stages, respectively. $\mathrm{i} M y c \mathrm{E} \mu$ mice also mimic $\mathrm{T}(12,15)$ mouse plasmacytoma translocation and thus also lead to plasmacytomas (68). KI of $c$-myc directly into $\mathrm{C}_{\alpha}$ just 5 ' to the 3'RR ( $\mathrm{iMycC}_{\alpha}$ mice) produced $\mathrm{B}$-cell lymphomas with low kinetics which were increased after overexpression of the anti-apoptotic Bcl- $\mathrm{X}_{\mathrm{L}}$ gene (69). In this model, c-myc is located in a site where $\mathrm{E}_{\mu}$ has no transcriptional influence, $c-m y c$ transcription being only under the dependence of 3 'RR at mature B-cell stages. $c-m y c \mathrm{KI}$ in the mouse $\mathrm{IgH}$ locus

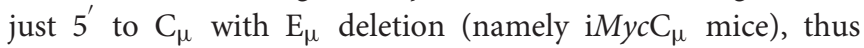
modeling human sporadic $\mathrm{BL}$, confirmed that $3^{\prime} \mathrm{RR}$ alone is sufficient to deregulate $c-m y c$ in the $\mathrm{B}$-cell lineage and to induce B-cell lymphoma development (70). Taken altogether, these KI models carrying $c-m y c$ at the $\mathrm{IgH}$ locus are prone to B-cell lymphomas of various penetrance, kinetics, and fate as recently reported in a study comparing the three mouse models (71). The lymphoma signatures are also heterogeneous even comparing lymphomas from a specific KI, mirroring the genomic differences observed between the various subtypes of human mature B-cell lymphomas and those previously reported with the model of transgenic $\mathrm{E}_{\mu}-M y c$ mice. In our opinion, these transgenic mouse models represent the "most physiological" experimental mouse models by mimicking the direct effect of c-myc in the context of the endogenous IgH locus. However, the main drawbacks of these various KI mice (and similarly to $M y c-3$ 'RR mice) remain their low lymphoma penetrance and their low kinetics of B-cell lymphoma development arguing against their use as efficient and easy experimental models to test new experimental therapeutic approaches. The low kinetics of B-cell lymphoma development compared with 3'RR-Myc mice would be related to the $3^{\prime} \mathrm{CBE}$ insulator region at the 3 ' boundary of the endogenous $\operatorname{IgH}$ locus $(72,73)$. This region is not present in the transgenic mouse model of 3 'RR-induced c-myc deregulation. The 3'CBE insulator region contains a high density of binding sites for CCCTC-binding factor (CTCF), a protein associated with mammalian insulator activity. Deletion of the 3'CBE insulator region resulted in significant effects on VDJ rearrangement, IgH locus compaction, and $\mathrm{IgH}$ locus insulation. Furthermore, physical interactions occur in B-cells between $3^{\prime} \mathrm{CBE}$ and $3^{\prime} \mathrm{RR}$ enhancers suggesting that the entire $3^{\prime}$ region (3'RR enhancers $+3^{\prime} \mathrm{CBE}$ insulators) works as a physical unit. The lack of 3'CBE in 3'RR-Myc mice could induced stronger and longer $\boldsymbol{c}$ - $m y c$ deregulation (and thus faster lymphoma emergence) than that obtained when $c$-myc is inserted

\section{REFERENCES}

1. Lieber MR. Mechanisms of human lymphoid chromosomal translocations. Nat Rev Cancer. (2016) 16:387-98. doi: 10.1038/nrc.2016.40

2. Pinaud E, Marquet M, Fiancette R, Peron S, Vincent-Fabert C, Denizot $\mathrm{Y}$, et al. The IgH locus 3' regulatory region: pulling the strings from behind. Adv Immunol. (2011) 110:27-70. doi: 10.1016/B978-0-12-387663-8.00 002-8 into the IgH locus under the control of the entire (enhancer + insulator) region.

\section{CONCLUSION}

Knock-out mice models have clarified the functions of $\mathrm{E}_{\mu}$ and 3'RR enhancers as essential for DNA remodeling and $\operatorname{IgH}$ locus transcription at specific stages of B-cell development and maturation. Thus, these enhancers have a major potential to be oncogene deregulators for IgH-translocated oncogenes, even when the breakpoints lie several $100 \mathrm{~kb}$ away from them. All these models contribute different but interesting data to our understanding of human B-cell lymphoma development and treatments especially with regards to the great functional and structural similarities found between human and mouse IgH loci (74). However, we must keep in mind that these mice are experimental models that do not reflect $100 \%$ of what happens in humans. For example, if the vast majority of human mature B-cell lymphomas are mutated in their VDJ region (highlighting their post-germinal center status) it is not the case in mice where mature B-cell lymphomas are unmutated (highlighting their pre-germinal center status) (75). Long-range loop interactions between chromatin segments of the IgH locus comprise the mechanism of normal and abnormal gene transcription regulation by the $3^{\prime} R R(2,76)$ (Figure 2B). Therefore, it is possible to suggest that targeted inhibition of the 3 'RR would be a therapeutic approach for the treatment of some mature B-cell lymphomas. Finally, it is also of importance to mention that the $c-m y c$ oncogene driven by Ig light chain enhancers also induces B-cell lymphoid malignancy in transgenic mice $(11,77)$. These models highlight not only the importance of all Ig enhancers for B-cell lymphoma development but also that a 3'RR targeting strategy (if any) would not be a silver bullet to treat all B-cell lymphomas but at best some mature B-cell subtypes.

\section{AUTHOR CONTRIBUTIONS}

All authors listed have made a substantial, direct and intellectual contribution to the work, and approved it for publication.

\section{FUNDING}

This work was supported by grants from Equipe Labellisée LIGUE 2018 and ANR Episwitch 2016. MF was supported by a grant from Université de Limoges and Région Nouvelle Aquitaine. NG and HI were supported by ANR Episwitch 2016. 
intron of a rearranged immunoglobulin heavy chain gene. Cell. (1983) 33:717-28. doi: 10.1016/0092-8674(83)90014-4

6. Banerji J, Olson L, Schaffner W. A lymphocyte-specific cellular enhancer is located downstream of the joining region in immunoglobulin heavy chain genes. Cell. (1983) 33:729-40. doi: 10.1016/0092-8674(83)90015-6

7. Perlot T, Alt FW, Bassing CH, Heikyung S, Pinaud E. Elucidation of IgH intronic enhancer functions via germ-line deletion. Proc Natl Acad Sci USA. (2005) 102:14362-7. doi: 10.1073/pnas.0507090102

8. Marquet M, Garot A, Bender S, Carrion C, Rouaud P, Lecardeur S, et al. The $\mathrm{E} \mu$ enhancer region influences $\mathrm{H}$ chain expression and $\mathrm{B}$ cell fate without impacting IgVH repertoire and immune response in vivo. J Immunol. (2014) 193:1171-83. doi: 10.4049/jimmunol.1302868

9. Saintamand A, Rouaud P, Garot A, Carrion C, Oblet C, Cogné M, et al. The $\operatorname{IgH} 3^{\prime}$ regulatory region governs $\mu$ chain transcription in mature B lymphocytes and the B cell fate. Oncotarget. (2015) 6:484552. doi: $10.18632 /$ oncotarget. 3010

10. Issaoui H, Ghazzaui N, Ferrad M, Boyer F, Denizo Y. Class switch recombination junctions are not affected by the absence of the immunoglobulin heavy chain $\mathrm{E}_{\mu}$ enhancer. Cell Mol Immunol. (2019) 16:671-3. doi: 10.1038/s41423-019-0229-x

11. Adams JM, Harris AW, Pinkert CA, Corcoran LM, Alexander W, Cory $\mathrm{S}$, et al. The c-myc oncogene driven by immunoglobulin enhancers induces lymphoid malignancy in transgenic mice. Nature. (1985) 318:5338. doi: 10.1038/318533a0

12. Hussain S, Bedekovics $\mathrm{T}$, Liu Q, Hu W, Jeon $\mathrm{H}$, Johnson $\mathrm{H}$, et al. UCH-L1 bypasses mTOR to promote protein biosynthesis and is required for MYC-driven lymphomagenesis in mice. Blood. (2018) 132:256474. doi: 10.1182/blood-2018-05-848515

13. Hussain S, Foreman O, Perkins SL, Witzig TE, Miles RR, van Deursen J, et al. The de-ubiquitinase UCH-L1 is an oncogene that drives the development of lymphoma in vivo by deregulating PHLPP1 and Akt signaling. Leukemia. (2010) 24:1641-55. doi: 10.1038/leu.2010.138

14. Gramling MW, Eischen CM. Suppression of Ras/Mapk pathway signaling inhibits Myc-induced lymphomagenesis. Cell Death Differ. (2012) 19:12207. doi: $10.1038 /$ cdd.2012.1

15. Nemajerova A, Petrenko O, Trümper L, Palacios G, Moll UM. Loss of p73 promotes dissemination of Myc-induced B cell lymphomas in mice. J Clin Invest. (2010) 120:2070-80. doi: 10.1172/JCI40331

16. Odvody J, Vincent T, Arrate M, Pgrieb B, Wang S, Garriga J, et al. A deficiency in $\mathrm{Mdm} 2$ binding protein inhibits Myc-induced B-cell proliferation and lymphomagenesis. Oncogene. (2010) 29:3287-96. doi: 10.1038/onc. 2010.82

17. Chen J, Shin JH, Zhao R, Phan L, Wang H, Xue Y, et al. CSN6 drives carcinogenesis by positively regulating Myc stability. Nat Commun. (2014) 5:5384. doi: 10.1038/ncomms6384

18. Wong DM, Li L, Jurado S, King A, Bamford R, Wall M, et al. The transcription factor ASCIZ and its target DYNLL1 are essential for the development and expansion of MYC-driven B cell lymphoma. Cell Rep. (2016) 14:148899. doi: 10.1016/j.celrep.2016.01.012

19. Kadariya Y, Tang B, Wang L, Al-Saleem T, Hayakawa K, Slifker MJ, et al. Germline mutations in Mtap cooperate with Myc to accelerate tumorigenesis in mice. PLoS ONE. (2013) 8:e67635. doi: 10.1371/journal.pone.0067635

20. Leong HS, Kelan C, Hilton DJ, Blewitt ME, Yifang HU, Lee S, et al. Epigenetic regulator Smchd 1 functions as a tumor suppressor. Cancer Res. (2012) 73:1591-9. doi: 10.1158/0008-5472.CAN-12-3019

21. Lu Y, Wu Y, Feng X, Shen R, Wang JH, Fallahi M, et al. CDK4 deficiency promotes genomic instability and enhances Myc-driven lymphomagenesis. $J$ Clin Invest. (2014) 124:1672-84. doi: 10.1172/JCI63139

22. Vandenberg CJ, Motoyama N, Cory S. FoxO3 suppresses Myc driven lymphomagenesis. Cell Death Dis. (2016) 7:e2046. doi: 10.1038/cddis.2015.396

23. Olive V, Sabio E, Bennett MJ, De Jong CS, Biton A, McGann JC, et al. A component of the mir-17-92 polycistronic oncomir promotes oncogenedependent apoptosis. Elife. (2013) 2:e00822. doi: 10.7554/eLife.00822

24. Chu B, Kon N, Chen D, Li T, Liu T, Jiang L, et al. ALOX12 is required for p53mediated tumour suppression through a distinct ferroptosis pathway. Nat Cell Biol. (2019) 21:579-91. doi: 10.1038/s41556-019-0305-6

25. Takahashi Y, Young MM, Serfass JM, Hori T, Wang HG. Sh3glb1/Bif-1 and mitophagy. Autophagy. (2013) 9:1107-9. doi: 10.4161/auto.24817
26. Tuzlak S, Haschka MD, Mokina AM, Rülicke T, Cory S, Labi V, et al. Differential effects of Vav-promoter-driven overexpression of BCLX and BFL1 on lymphocyte survival and B cell lymphomagenesis. FEBS J. (2018) 285:1403-18. doi: 10.1111/febs.14426

27. Sochalska M, Schuler F, Weiss JG, Prchal-Murphy M, Sexl V, Villunger A. MYC selects against reduced BCL2A1/A1 protein expression during B-cell lymphomagenesis. Oncogene. (2017) 36:2066-73. doi: 10.1038/onc.2016.362

28. Nguyen HV, Vandenberg CJ, Ng AP, Robati MR, Anstee NS, Rimes J, et al. Development and survival of MYC-driven lymphomas require the Myc antagonist MNT to curb MYC-induced apoptosis. Blood. (2020) 135:101931. doi: 10.1182/blood.2019003014

29. Vecchio E, Fiume G, Mignogna C, Iaccino E, Mimmi S, Maisano D, et al. IBTK haploinsufficiency affects the tumor microenvironment of Myc-driven lymphoma in E-myc mice. Int J Mol Sci. (2020) 21:885. doi: 10.3390/ijms21030885

30. Rehm A, Mensen A, Schradi K, Gerlach K, Wittstock S, Winter S, et al. Cooperative function of CCR7 and lymphotoxin in the formation of a lymphoma-permissive niche within murine secondary lymphoid organs. Blood. (2011) 118:1020-33. doi: 10.1182/blood-2010-11-321265

31. Cao Z, Ding BS, Guo P, Lee SB, Butler JM, Casey C, et al. Angiocrine factors deployed by tumor vascular niche induce B cell lymphoma invasiveness and chemotresistance. Cancer Cell. (2014) 25:350-65. doi: 10.1016/j.ccr.2014.02.005

32. Reimann M, Lee S, Loddenkemper C, Dorr JR, Tabor V, Aichele $\mathrm{P}$, et al. Tumor stroma-derived TGF-b limits myc-driven lymphomagenesis via Suv39h1-dependent senescence. Cancer Cell. (2010) 17:262-72. doi: 10.1016/j.ccr.2009.12.043

33. Sauer M, Schuldner M, Hoffmann N, Cetintas A, Reiners KS, Shatnyeva O, et al. CBP/p300 acetyltransferases regulate the expression of NKG2D ligands on tumor cells. Oncogene. (2017) 36:933-41. doi: 10.1038/onc.2016.259

34. Rehm A, Gätjen M, Gerlach K, Scholz F, Mensen A, Gloger M, et al. Dendritic cell-mediated survival signals in $\mathrm{E} \mu$-Myc B-cell lymphoma depend on the transcription factor C/EBP $\mu$. Nat Comm. (2014) 5:5057. doi: $10.1038 /$ ncomms6057

35. Lasorsa E, Smonksey M, Kirk JS, Rosario S, Hernandez-Ilizaliturri FJ, Ellis L, et al. Mitochondrial protection impairs BET bromodomain inhibitor-mediated cell death and provides rationale for combination therapeutic strategies. Cell Death Dis. (2015) 6:e2014. doi: 10.1038/cddis.20 15.352

36. Hogg SJ, Newbold A, Vervoort SJ, Cluse LA, Martin BP, Gregory P, et al. BET inhibition induces apoptosis in aggressive B-cell lymphoma via epigenetic regulation of BCL-2 family members. Mol Cancer Ther. (2016) 15:203041. doi: 10.1158/1535-7163.MCT-15-0924

37. Lin CJ, Robert F, Sukarieh R, Michnick S, Pelletier J. The antidepressant sertraline inhibits translation initiation by curtailing mammalian target of rapamycin signaling. Cancer Res. (2010) 70:3199-208. doi: 10.1158/0008-5472.CAN-09-4072

38. Rava M, D'Andrea A, Nicoli P, Gritti I, Donati G, Doni M, et al. Therapeutic synergy between tigecycline and venetoclax in a preclinical model of Myc/BCL2 double-hit B cell lymphoma. Sci Transl Med. (2018) 10:eaan8723. doi: 10.1126/scitranslmed.aan8723

39. Ross J, Rashkovan M, Fraszczak J, Beauparlant CJ, Vadnais C, Winkler $\mathrm{R}$, et al. C and B-ALL/lymphoma mouse models. Cancer Res. 79:418495. doi: 10.1158/0008-5472.CAN-18-3038

40. Reiff SD, Mantel R, Smith LL, Greene JT, Muhowski EM, Fabian A, et al. The BTK inhibitor ARQ531 targets ibrutinibresistant CLL and richter transformation. Cancer Discov. (2018) 8:1300-15. doi: 10.1158/2159-8290.CD-17-1409

41. Wall M, Poortinga G, Stanley KL, Lindemann RK, Bots M, Chan J, et al. The mTORC1 inhibitor everolimus prevents and treats em-Myc lymphoma by restoring oncogene-induced senescence. Cancer Discov. (2013) 3:8295. doi: 10.1158/2159-8290.CD-12-0404

42. Rodrigo M, Cencic R, Roche SP, Pelletier J, Porco JA Jr. Synthesis of rocaglamide hydroxamates and related compounds as eukaryotic translation inhibitors: synthetic and biological studies. J Med Chem. (2012) 55:55862. doi: $10.1021 / \mathrm{jm} 201263 \mathrm{k}$

43. Mattarollo SR, West AC, Steegh K, Duret H, Paget C, Martin $\mathrm{B}$, et al. NKT cell adjuvant-based tumor vaccine for treatment 
of myc oncogene-driven mouse B-cell lymphoma. Blood. (2012) 120:3019-29. doi: 10.1182/blood-2012-04-426643

44. Kobayashi T, Doff BL, Rearden RC, Leggatt GR, Mattarollo SR. NKT cell-targeted vaccination plus anti-4-1BB antibody generates persistent CD8 T cell immunity against B cell lymphoma. OncoImmunology. (2015) 4:e990793. doi: 10.4161/2162402X.2014.990793

45. Croxford JL, Tang ML, Pan MF, Huang CW, Kamran N, Phua M, et al. ATM-dependent spontaneous regression of early E $\mu$-myc-induced murine B-cell leukemia depends on natural killer and T cells. Blood. (2013) 121:251221. doi: 10.1182/blood-2012-08-449025

46. Westwood JA, Matthews GM, Shortt J, Faulkner D, Pegram HJ, Duong $\mathrm{P}$, et al. Combination anti-CD137 and anti-CD40 antibody therapy in murine myc-driven hematological cancers. Leukemia Res. (2014) 38:94854. doi: 10.1016/j.leukres.2014.05.010

47. Johnston HE, Carter MJ, Cox KL, Dunscombe M, Manousopoulou A, Townsend A, et al. Integrated cellular and plasma proteomics of contrasting B-cell cancers reveals common unique and systemic signatures. Mol Cell Proteomics. (2017) 16:386-406. doi: 10.1074/mcp.M116.063511

48. Rempel RE, Jiang X, Fullerton P, Tan TZ, Ye J, Lau A, et al. Utilization of the $\mathrm{E} \mu$-Myc mouse to model heterogeneity of therapeutic response. Mol Cancer Ther. (2014) 13:3219-29. doi: 10.1158/1535-7163.MCT-13-0044

49. Guglielmi L, Truffinet V, Carrion C, Le Bert M, Cogné N, Cogné M, et al. The 5'HS4 insulator element is an efficient tool to analyse the transient expression of an E $\mu$-GFP vector in a transgenic mouse model. Trans Res. (2005) 14:361-4. doi: 10.1007/s11248-005-3239-7

50. Ghazzaui N, Issaoui H, Boyer F, Martin OA, Saintamand A, Denizot Y. 3'RR and $5^{\prime} \mathrm{E} \mu$ immunoglobulin heavy chain enhancers are independent engines of locus remodeling. Cell Mol Immunol. (2019) 16:198-200. doi: 10.1038/s41423-018-0171-3

51. Saintamand A, Vincent-Fabert C, Garot A, Rouaud P, Oruc Z, Magnone $\mathrm{V}$, et al. Deciphering the importance of the palindromic architecture of the immunoglobulin heavy chain 3' regulatory region. Nat Commun. (2016) 7:10730. doi: $10.1038 /$ ncomms10730

52. Vincent-Fabert C, Fiancette R, Pinaud E, Truffinet V, Cogné N, Cogné M, et al. Genomic deletion of the whole IgH 3' regulatory region (hs3a, hs1,2, hs $3 b$, hs4) dramatically affects class switch recombination and Ig secretion to all isotypes. Blood. (2010) 116:1895-98. doi: 10.1182/blood-2010-01-264689

53. Saintamand A, Rouaud P, Saad F, Rios G, Cogné M, Denizot Y. Elucidation of IgH 3' region regulatory role during class switch recombination via germline deletion. Nat Commun. (2015) 6:7084. doi: 10.1038/ncomms8084

54. Rouaud P, Vincent-Fabert C, Saintamand A, Fiancette R, Marquet M, Robert I, et al. The IgH 3' regulatory region controls AID-induced somatic hypermutation in germinal centre B-cells in mice. J Exp Med. (2013) 210:1501-7. doi: $10.1084 / \mathrm{jem} .20130072$

55. Guglielmi L, Le Bert M, Truffinet V, Cogné M, Denizot Y. Insulators to improve expression of a $3^{\prime} \mathrm{IgH}$ LCR-driven reporter gene in transgenic mouse models. Biochem Biophys Res Commun. (2003) 307:466-71. doi: 10.1016/S0006-291X(03)01185-9

56. Madisen L, Groudine M. Identification of a locus control region in the immunoglobulin heavy-chain locus that deregulates C-Myc expression in plasmacytoma and Burkitt's lymphoma cells. Genes Dev. (1994) 8:221226. doi: $10.1101 /$ gad.8.18.2212

57. Gostissa M, Yan CT, Bianco JM, Cogné M, Pinaud E, Alt FW. Long-range oncogenic activation of Igh-c-myc translocations by the Igh 3' regulatory region. Nature. (2009) 462:803-8. doi: 10.1038/nature08633

58. Kovalchuk AL, Sakai T, Qi CF, Du Bois W, Dunnick WA, Congé M, et al. (2018) 3'Igh enhancers hs3b/hs4 are dispensable for Myc deregulation in mouse plasmacytomas with $\mathrm{T}(12 ; 15)$ translocations. Oncotarget. 9:3452842. doi: $10.18632 /$ oncotarget. 26160

59. Wang J, Boxer LM. Regulatory elements in the immunoglobulin heavy chain gene 3'-enhancers induce c-myc deregulation and lymphomagenesis in murine B cells. J Biol Chem. (2006) 280:12766-73. doi: 10.1074/jbc.M412446200

60. Truffinet V, Pinaud E, Cogné N, Petit B, Guglielmi L, Cogné M, et al. The 3' IgH locus control region is sufficient to deregulate a c-myc transgene and promote mature $\mathrm{B}$ cell malignancies with a predominant Burkitt-like phenotype. J Immunol. (2007) 179:603342. doi: 10.4049/jimmunol.179.9.6033
61. Fiancette R, Rouaud P, Vincent-Fabert C, Laffleur B, Magnone V, Cogné $\mathrm{M}$, et al. A p53 defect sensitizes various stages of B cell development to lymphomagenesis in mice carrying an $\mathrm{IgH} 3$ ' regulatory region-driven $\mathrm{c}$ myc transgene. J Immunol. (2011) 187:5772-82. doi: 10.4049/jimmunol.11 02059

62. Vincent-Fabert C, Fiancette R, Rouaud P, Baudet C, Truffinet V, Magnone $\mathrm{V}$, et al. A defect of the INK4-Cdk4 checkpoint and c-myc collaborate in blastoid mantle cell lymphoma (MCL)-like lymphoma formation in mice. Am J Pathol. (2012) 180:1688-701. doi: 10.1016/j.ajpath.2012. 01.004

63. Rouaud P, Fiancette R, Vincent-Fabert C, Magnone V, Cogné M, Dubus P, et al. Mantle cell lymphoma-like lymphomas in c-myc-3'RR/p53+/- mice and c-myc-3'RR/Cdk4R24C mice: differential oncogenic mechanisms but similar cellular origin. Oncotarget. (2012) 3:586-93. doi: 10.18632/oncotarg et. 474

64. Amin R, Marfak A, Pangault C, Oblet C, Chanut A, Tarte K, et al. The class-specific BCR tonic signal modulates lymphomagenesis in a c-myc deregulation transgenic model. Oncotarget. (2014) 15:8995-9006. doi: 10.18632/oncotarget.2297

65. Vincent-Fabert C, Fiancette R, Truffinet V, Cogné N, Cogné M, Denizot Y. Genetic background modulates susceptibility to oncogen-driven proliferation and lymphoma occurrence in mice carrying a deregulated c-myc transgene. Leuk Res. (2009) 33:e203-6. doi: 10.1016/j.leukres.2009. 05.018

66. Park SS, Kim JS, Tessarollo L, Owens JD, Peng L, Su Han S, et al. Insertion of c-Myc into Igh induces B-cell and plasma-cell neoplasms in mice. Cancer Res. (2005) 65:1306-15. doi: 10.1158/0008-5472.CAN-0 4-0268

67. Han SS, Yun H, Son DJ, Tompkins VS, Peng L, Chung T, et al. NFkappaB/STAT3/PI3K signaling crosstalk in iMyc E mu B lymphoma. Mol Cancer. (2010) 9:97. doi: 10.1186/1476-4598-9-97

68. Park SS, Shaffer AL, Kim JS, Dubois W, Potter M, Staudt M, et al. Insertion of Myc into Igh accelerates peritoneal plasmacytomas in mice. Cancer Res. (2005) 65:7644-52. doi: 10.1158/0008-5472.CAN-0 $5-1222$

69. Cheung WC, Kim JS, Linden M, Peng L, Van Ness B. Novel targeted deregulation of c-myc cooperates with Bcl-XL to cause plasma cell neoplasms in mice. J Clin Invest. (2004) 113:1763-73. doi: 10.1172/JCI2004 20369

70. Rosean TR, Holman CJ, Tompkins VS, Jing X, Krasowski MD, RoseJohn S, et al. KSHV-encoded vIL6 collaborates with deregulated cMYC to drive plasmablastic neoplasm in mice. Blood Cancer J. (2016) 6:e398. doi: 10.1038/bcj.2016.6

71. Ghazzaui N, Issaoui H, Ferrad M, Carrion C, Cook-Moreau J, Denizot $\mathrm{Y}$, et al. $\mathrm{E} \mu$ and $3^{\prime} \mathrm{RR}$ transcriptional enhancers of the $\operatorname{IgH}$ locus cooperate to promote c-myc-induced mature B-cell lymphomas. Blood Adv. (2020) 4:28-39. doi: 10.1182/bloodadvances.20190 00845

72. Volpi SA, Verma-Gaur J, Hassan R, Ju Z, Roa S, Chatterjee S, et al. Germline deletion of Igh $3^{\prime}$ regulatory region elements hs 5, 6, 7 (hs57) affects $B$ cell-specific regulation, rearrangement, and insulation of the Igh locus. J Immunol. (2012) 188: 2556-66. doi: 10.4049/jimmunol.11 02763

73. Birshtein BK. Epigenetic regulation of individual modules of the immunoglobulin heavy chain locus 3' regulatory region. Front Immunol. (2014) 5:163. doi: 10.3389/fimmu.2014.00163

74. D’addabbo P, Scascitelli M, Giambra V, Rocchi M, Frezza D. Position and sequence conservation in amniota of polymorphic enhancer HS1,2 within the palindrome of IgH 3' regulatory region. BMC Evol Biol. (2011) 11:71. doi: 10.1186/1471-2148-11-71

75. Saintamand A, Garot A, Saad F, Moulinas R, Denizot Y. Pregerminal center origin for mature mouse B cell lymphomas: a major discrepancy with human mature lymphomas. Cell Cycle. (2015) 14:3656-8. doi: 10.1080/15384101.2015.10 93708

76. Duan H, Xiang H, Ma L, Boxer LM. Functionals long-range interactions of the IgH 3' enhancers with the bcl-2 promoter region in $\mathrm{t}(14 ; 18)$ lymphoma cells. Oncogene. (2008) 27:6720-8. doi: 10.1038/onc.2008.286 
77. Kovalchuk AL, Qi CF, Torrey TA, Taddesse-Heath L, Feigenbaum L, Park SS, et al. Burkitt lymphoma in the mouse. J Exp Med. (2000) 192:118390. doi: $10.1084 /$ jem.192.8.1183

Conflict of Interest: The authors declare that the research was conducted in the absence of any commercial or financial relationships that could be construed as a potential conflict of interest.
Copyright $(2020$ Ferrad, Ghazzaui, Issaoui, Cook-Moreau and Denizot. This is an open-access article distributed under the terms of the Creative Commons Attribution License (CC BY). The use, distribution or reproduction in other forums is permitted, provided the original author(s) and the copyright owner(s) are credited and that the original publication in this journal is cited, in accordance with accepted academic practice. No use, distribution or reproduction is permitted which does not comply with these terms. 